The University of Maine

DigitalCommons@UMaine

Maine Bicentennial

Special Collections

1947

\title{
Early Days of the Maine State Prison at Thomaston
}

Negley K. Teeters

Temple University

Follow this and additional works at: https://digitalcommons.library.umaine.edu/mainebicentennial

Part of the Criminology and Criminal Justice Commons, and the United States History Commons

\section{Recommended Citation}

Teeters, Negley K., "Early Days of the Maine State Prison at Thomaston" (1947). Maine Bicentennial. 122.

https://digitalcommons.library.umaine.edu/mainebicentennial/122

This Book is brought to you for free and open access by DigitalCommons@UMaine. It has been accepted for inclusion in Maine Bicentennial by an authorized administrator of DigitalCommons@UMaine. For more information, please contact um.library.technical.services@maine.edu. 


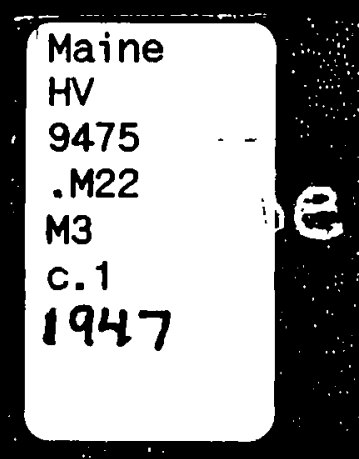

STATE OF MANS

Teeters, $\mathrm{H} . \mathrm{K}$. COLLECTIOH

Farly days of the Maine Strte Prison at Thomaston 


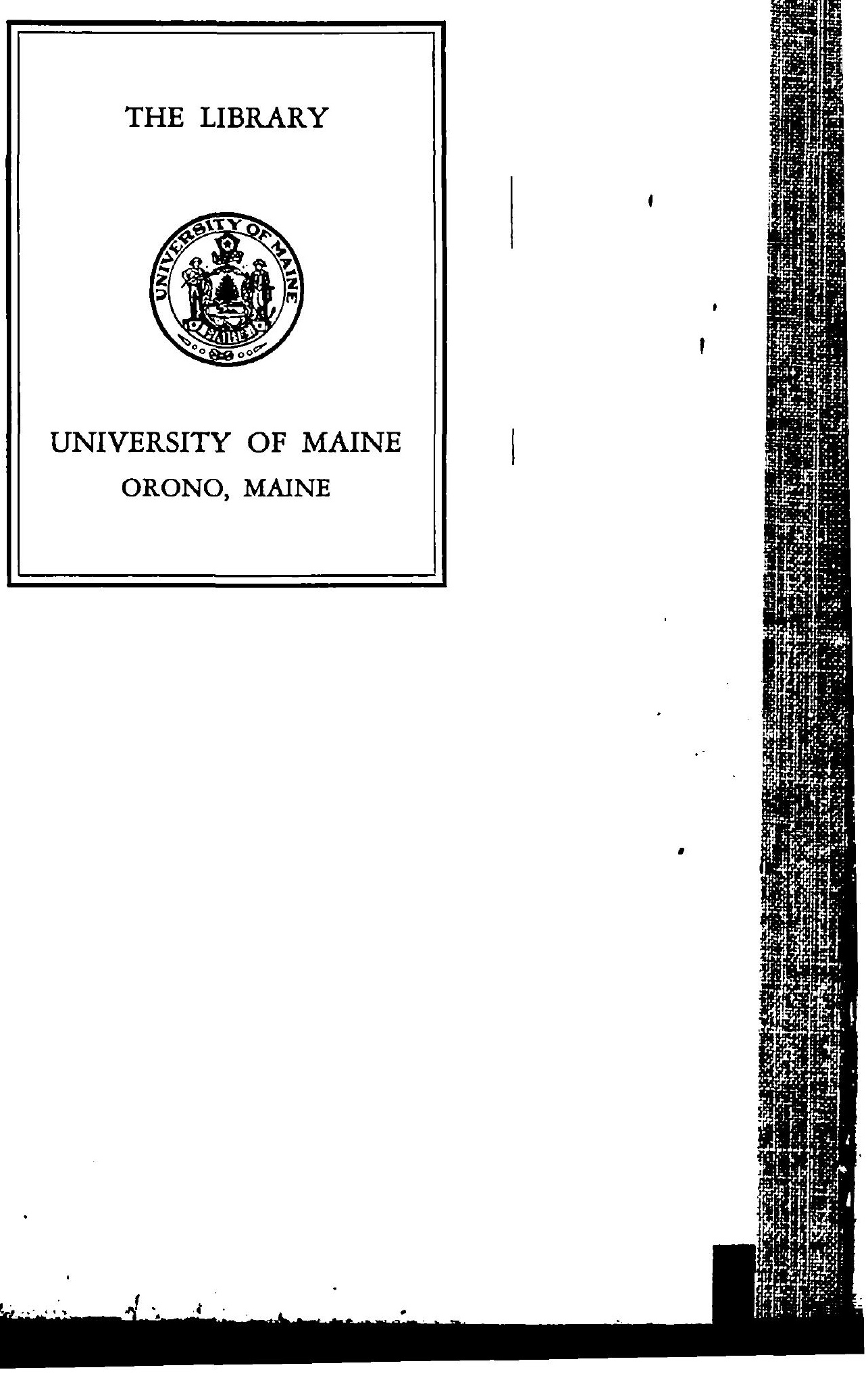




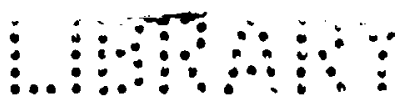

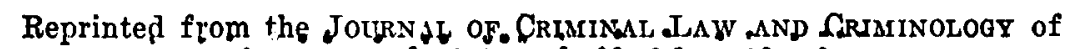
$:::::$ Nonthwestern tonivergitj: $: \because: \vdots$ $\because: \because$ Vol. 38 , Nó. 2 , July-August, $1947^{\circ}:$.

\section{EARIY DAYS OF THE MAINE STATE PRISON AT THOMASTON}

\section{Negley K. Teeters}

The author is Professor of Criminology in Temple University, Philadelphia. He is author of World Penal Systems, 1944, Penology from Panama to Cape Horn, 1946, and co-author (with Professor Harry E. Barnes) of New Horizons in Criminology, 1943.

Professor Teeters acknowledges his indebtedness to Mrs. Marion Cobb Fuller, Research Librarian of the Maine State Library, for valuable assistance in locating documents and other source material he has used in this article.-EDIToR.

Prior to separation of Maine territory from Massachusetts in 1820 , convicted felons from that area were sent to the prisons of the Bay State, first to the one on Castle Island in Boston Harbor and, after 1805, to the Charlestown penitentiary located on Lynd's Point.

As early as February 9, 1822 "the Hon. D[aniel] Rose, Hon. John Chandler and Hon. William Pitt Preble were appointed a Commission pursuant to two Resolves of the Legislature to take into Consideration the punishment of Convicts and the erection of a state Prison and the Selection of a place for the permanent seat of Government."

The next move of the legislature occurred on February 1, 1823 when an act was passed which provided for the creation as well as the "directing and governing" of a state prison and on February 10 a Commission consisting of Dr. Daniel Rose of Boothbay, Benjamin Ames of Bath, and Thomas Bond of Hallowell were "appointed under the first section of the act to provide for the erection and government of a state prison, a committee to purchase for the State a suitable lot of land in the town of Thomaston on which to erect such prison and other buildings necessary for the employment of convicts." ${ }_{2}$ On the next day, February 11, 1823 the "Hon. D. Rose [was] appointed an agent whose duty it shall be to superintend the erection of said prison." 3

It would seem from the above that the first Commission selected Thomaston as a site for the prison and the second picked out the exact parcel of land. The reasons for Thomaston being selected was because "it was halfway between Kittery and Eastport" and was in the thickest populated part of the state at that time. ${ }^{4}$

1 Council Records, February 9, 1822.

2 Ibid., February 10, 1823.

3 Ibid., February 11, 1823.

4 Stated in Warden E. H. Waterhouse's report of 1915. 


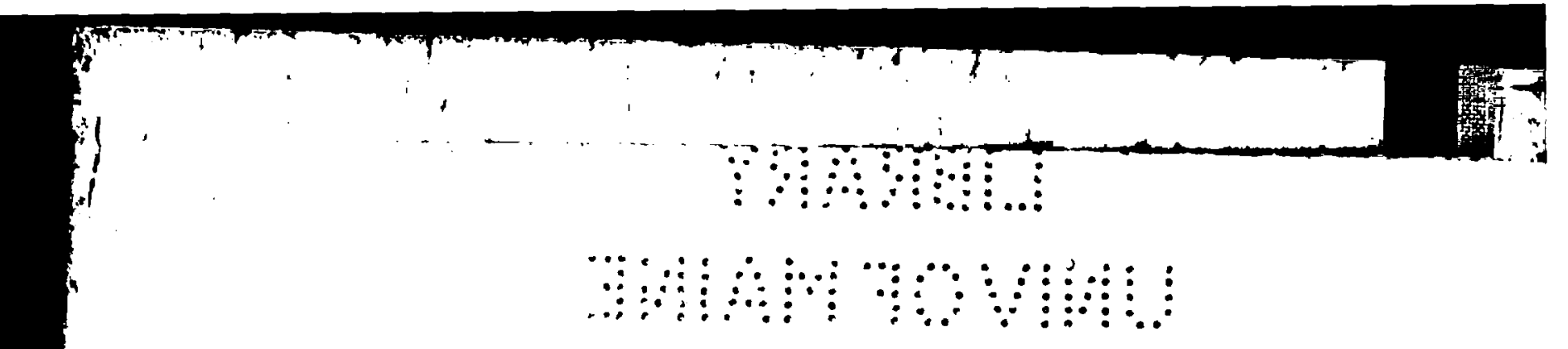


The site was selected by the Commission on May 7, 1823. It was a ten acre tract known as Limestone Hill and was owned by ex-Governor William King. The price was $\$ 3,000$. The land had for many years been used as a quarry, first by its original owner and later by General Henry Knox-Revolutionary War hero. The area extended from Main Street to George's River.

An act was passed by the legislature on February 1, 1824 calling for the complete administration of the newly-established prison as well as for the appointment of two chaplains-the Rer. John H. Ingraham and the Rev. Job Washburn. The diet of the prisoners-the so-called "hard labor" men-was also provided for at that time. It is of interest to record the diet:

for breakfast three gills of Indian meal made into a hasty pudding or half a pound of course [sic] bread and half a gill of molasses and the same for supper. For dinner from ten to fourteen ounces of beef, according to quality of same, or one-half of salted pork and a half pint of peas or beans or one-half pound of dry fish or a pound of fresh fish with an ounce of hog's lard or butter; and with these shall be allowed a half pound of bread and half a pint of potatoes or a pint when allowed fish. The drink shall be water except in summer and if the health of the prisoner shall require it they may be allowed spruce or hop beer. ${ }^{5}$

Quite early in 1824 there was considerable discussion concerning the establishment of a militia in and around Thomaston "for security purposes" but it was not finally organized until June $24,1825 .{ }^{6}$

The work on the new prison began immediately after the site had been agreed upon so that by the middle of July, 1823, some fifty men were hard at work together with two lighters transporting granite from St. George. Governor Albion K. Parris inspected the work on October 15 and the preliminary job was completed by November 24 . Other minor contracts were let and the opening of the institution took place July $1,1824 .^{7}$

The cost of the original prison, except for the site, amounted to $\$ 30,768.46$, appropriated as follows : 1823 , ending January 22 , $1824, \$ 23,910.55$; 1824 , ending January $3,1825, \$ 4231.52 ; 1825$, ending December 15, 1825, $\$ 2007.08$; and 1826, ending November $30,1826, \$ 619.31$. However, according to a report to Governor Lincoln submitted by Attorney General Erastus Foote, January 1829 , the original expense amounted to $\$ 46,553.16$. This sum included such "dependences and appertenances" as a wharf, a loading gondola, erected by Warden Rose, and other such paraphernalia.

5 Council Record, April 29, 1824

6 Created by act of February $25,1824$.

7 Cyrus Eaton, History of Thomaston, Rockland and South Thomaston, Maine, Hallowell, 1865, p. 335. 
Among the first convicts to arrive at the new prison was a boatful from the Charlestown, Massachusetts institution-fourteen in number-and added to those previously sent there by the Maine judges the number on July 14, 1824, two weeks after opening day, was 35 . They were immediately put to work quarrying limestone. Those sentenced to solitary confinement were not "permitted" to labor. A discussion of the two types of sentence will be stated below.

The first warden of this prison was the colorful Dr. Daniel Rose, a member of the site commission, a well-known physician and a powerful politician of the new state of Maine. It is alleged that Dr. Rose had definite ideas on penology and was given carte blanche, not only as to running the prison but even as to its erection. Whether this is literally true or not, the first Maine prison represented a most unique architecture. A writer, reminiscing on the early days of the prison, recorded in the Rockland Courier-Gazette that Dr. Rose, Esq. had entire liberty to make the prison "after his own heart" and added cryptically : "The structure bore internal evidence that safety and surety to keep a prisoner was the controlling idea in his mind, all sanitary and humanitarian considerations being kept in abeyance."

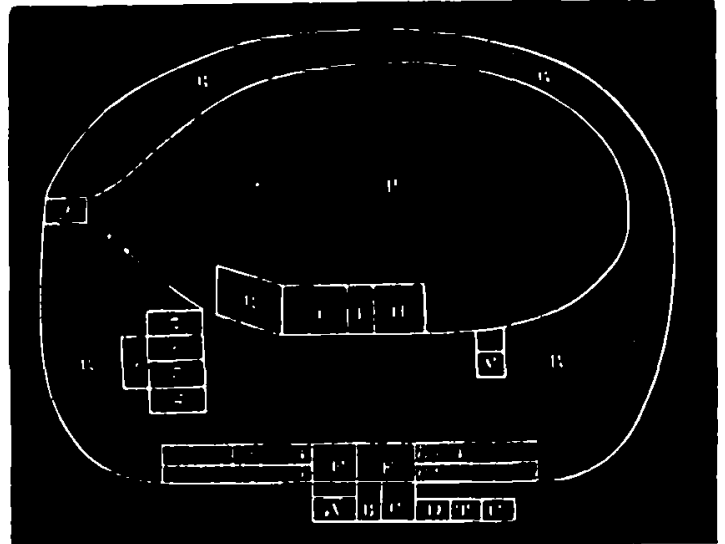

Ground View of the Maine PRISON.

A, B, C, E, F, apartments in the keeper's house, which is 40 feet by 50 , and two stories high; $D, T, U$, store rooms in a one story building; $i$, i, cells about 9 feet long, 4 1-2 wide, and ten feet high; H, I, J, K, V, small shops, some one and some two stories; $\mathrm{L}, \mathrm{M}, \mathrm{N}, \mathrm{O}, \mathrm{S}$, apartments in a two story building used for a kitchen, dining hall, store rooms, shops; $R, R$, yard; $P$, quarry; $Q$ entrance to the quarry and yard.

Scale 80 feet to an inch.

Because of the uniqueness of this fantastic architectural structure a description of it is of considerable moment, especially since contemporary prints are unavailable. ${ }^{9}$ The prison was composed of a center and two wings, the central portion being designed for the keeper's residence, hospital, etc., while the wings were devoted to cells or, rather, housing for the prisoners. Each of these wings consisted of two rows of cells abutting each

8 September 7, 1886.

9 A diagram of the prison is sketched in the second annual report of the Boston Prison Discipline Society, June 1, 1827. It is reproduced here. 
other across the wings. The cells, which were in reality holes in the earth, were 4 feet 6 inches $\times 8$ feet 9 inches and 9 feet 8 inches deep. The only entrance to these holes was a two foot square aperture in the top so that a ladder could be inserted by which the prisoner could descend to his subterranean abode. The commentator mentioned above stated:

They [the holes] were literally jugs in which the prisoner could fully and fearfully realize that he was truly jugged. The only communication with the outside world for light and ventilation was an upright aperture in the wall, some three feet in length by two inches in breadth. The apertures were always open even in the most inclement weather unless a prisoner could contrive to stuff his clothes therein. When a driving snowstorm came on his side of the prison he had therefore no choice but to let the rain and the snow blow on his head. ${ }^{10}$

He added that in order to cleanse these "jugs" water had to be let down from the top. What heating was furnished was let into the cells from a furnace through a small conductor one and a half inches in diameter.

Iron gratings covered the cell holes when the prisoners were immured and these were secured by means of a bar extending from the grating, on the sides opposite the hinges, which shut down over a staple and were fastened by a stout padlock. Each pair of grating was secured by one staple and one padlock. There were 28 cells in the east wing and 22 in the west.

Over each block of cells was erected a covering of wood with upright posts seven feet high to the roof. The sides of these coverings were composed in part of large doors on rollers; so that, when rolled back, one half of each side was open for free circulation of air over the tops of the cells. At night the doors were rolled back into place. The wings of the building were of two stories, the lower one of stone, the upper of wood. The Rockland commentator, mentioned above, stated that the open room over the cells was 10 or 12 feet high, surrounded by iron gratings, composed of round bars firmly secured at top and bottom and in the middle passing through flat iron bars six inches apart.

Around the entire reservation of the prison was a wooden fence sixteen feet high. The Council Records of November 22 1824 mentions that there was a plank walk outside the fence for guards to patrol. Many years later wardens begged the legislature for funds with which to build a new fence since the original boards were gradually disintegrating.

This bizarre Maine prison was exceeded in its uniqueness only by its colorful first warden, Dr. Daniel Rose of Boothbay, Wis-

10Loc. Cit. 
casset and later, Thomaston. Born at North Bradford, Connecticut, on July 31,1772 , he was educated at Yale were he graduated in 1791. He settled in New Milford (now Alna) near Boothbay in what was then Massachusetts. He studied medicine and practiced in Boothbay and later at Wiscasset. In this latter town he became a leader in politics as well as in his profession. In the War of 1812 he served as a captain of engineers and after the end of that conflict devoted himsèlf to his profession, as well as to his cherished hobby, politics. He became a leader in the separatist movement and after Maine became an independent state was elected to the senate and became president of that body from 1822 to 1824 . He actually served as Governor of the state for three days-January 2 to 5 -in 1822, between administrations. ${ }^{11}$

It was about this time-1822-when Dr. Rose became obsessed with unique ideas regarding the reformation of criminals. He had enough political influence to be given authority to erect the prison described above, which was without question the most unique institution of its kind in the history of American penology. The closest resemblance to the Maine prison was the underground copper mine at Granby [Simsbury] Connecticut which was in operation as early as colonial times. But here the state authorities merely took advantage of a mine in which to house its felons. At Thomaston cells were actually $d u g$ in the ground.

Little has been learned concerning Dr. Rose's views on penology and certainly there is some mystery as to the source of his architectural ideas. However, there is a recorded statement that he is alleged to have made regarding the type of treatment that should be meted out to those sentenced to imprisonment. It is quoted below :

State prisons should be so constructed that even their aspect might be terrific, and appear like what they should be, dark and comfortless abodes of guilt and wretchedness. No mode or degree of punishment which ever has been made or which ever can be adopted is in its nature so well adapted to purposes of preventing crime and reforming a criminal, as close confinement in a silent or solitary cell, in which, cut off from all hope of relief during the term for which he shall have been sentenced, the convict shall be furnished with a hammock on which he may sleep, a block of wood on which he may sit, and with such coarse, though wholesome food as may be best suited to a person in a situation designed for grief and penitence; and shall be favored with so much light from the firmament, as may enable him to read the New Testament, which shall be given him as his sole companion and guide to a better life. There his vices and crimes shall become personified, and appear

11 Short biographical sketch in James A. Spaulding, Maine Physicians, Lewiston, 1928, pp. 146-8. 
to his frightened imagination as the co-tenants of his dark and dismal cell. They will surround him as so many hideous spectres, and overwhelm him with horror and remose. ${ }^{12}$

The incumbency of Dr. Rose at the prison was from its inception in 1822-3 to 1828. After his retirement he became land agent with headquarters at Augusta. He died at Thomaston October 25, 1833 aged 61.

Warden Rose was a conspicuous person with his six feet of height and two hundred pounds weight. He always carried a heavy ironwood cane and excelled as a horseman. As stated above it is not known where he gained his ideas on penology but, aside from those dealing with the underground cells, they were not unusual for those days. His horrible imprecations quoted above sound like those uttered by the better-known Edward Livingston (1764-1836) of New York and later of Louisiana:

In this cell is confined, to pass his life in solitude and sorrow, A.B., convicted of the murder of C.D.; his food is bread of the coarsest kind, his drink is water, mingled with his tears; he is dead to the world; his eell is his grave; his existence is prolonged, that he may remember his crime and repent it, and that the continuance of his punishment may deter others from the indulgence of hatred, avarice, sensuolity, and the passions which led to the crime he has committed. When the Almighty, in his due time, shall exercise toward him that dispensation which he himself arrogantly and wickedly usurped toward another, his body is to be dissected, and his soul will abide that judgment which Divine Justice shall decree. ${ }^{13}$

Since the number of cells provided for in the two wings of the Maine prison was only 56 , it was soon obvious that with the added increase of prisoners new cells would have to be constructed. In fact Warden Rose was obliged to resort to placing two men in a cell. This probably was not a violation of the separate provision stipulated by law since some men were not sentenced to solitary confinement. For example, the report of the inspectors for 1826 stated:

Of fifty-eight convicts received into the State Prison during the last year, thirteen were sentenced to be punished by solitary imprisonment alone. Many of those who are sentenced to be confined to hard labor, have also to endure a large proportion of solitary confinement. ${ }^{14}$

So in 1828 a contract was entered into with Joseph Berry of Thomaston to erect or, rather, dig and construct twenty additional cells for the sum of $\$ 4,625$.

12 From minority report [James Woodbury of Bangor] of Commissioners on the Removal of the Maine State Prison, 1891. Majority-E. $\mathrm{H}$. Lawry and W. $\mathrm{H}$. Jackson. The majority report is a beautiful example of sophistry, if not sheer nonsense.

13Quoted by F. H. Wines, Punishment and Reformation, 1895 ed. p. 145, from Livingston's System of Penal Law for the State of Louisiana.

14 Boston Prison Discipline Society report, (Second) June 1, 1827, p. 84. 
When Dr. Rose resigned on July 1 of 1826 and Joel Miller, Esq. succeeded him he found these cells unfit for the housing of convicts so far as security was concerned. A group of new inspectors also came into office at that time and they made a tour of inspection. Several irregularities were immediately discovered. First, the new cells were insecure-in fact, one of the inspectors allowed himself to be let down into one and the iron grating above padlocked and he escaped in less than a minutesecond, the trustees of the Mariners' Church of Portland were clamoring for stone which had been promised them by Dr. Rose but which had not been delivered and was thus causing thousands of dollars loss in delayed construction. In due time, however, these minor irritations were adjusted but not before $\mathrm{Dr}$. Rose had paid a visit to Thomaston from his new loome in Augusta and explained how everything had happened. Joseph Berry also agreed to finish up lis cells so that they would be more secure.

The system under which the Maine prison was construeted and administered was that known as the Pennsylvania or separate system which called for continuous separate confinement, one prisoner from another. Nevertheless, many convicts were not thus sentenced and were put to work quarrying stone in "association" as soon as the institution was opened. It is possible there was no actual communication permitted between the prisoners thus working together but within a few years all semblance of the Pennsylvania system was abolished by law [1827]. Fannie S. Chase is the authority for stating that Dr. Rose "discouraged solitary confinement of prisoners," 15 but certainly a man stern (if not cruel) enough to place human beings in underground tombs even at night should not have quaked in the face of solitary confinement, especially when the docile Quakers of Philadelphia looked upon such treatment as mild and even humane. But perhaps Warden Rose deplored seeing so much manpower going to waste as the prisoners sentenced to solitary confinement languished in their lonely hammocks. Rev. Louis Dwight, secretary of the Boston Prison Discipline Society, writing on the Thomaston- establishment in the 1827 report states that "one third of the convicts who have been discharged . . . were sentenced to suffer solitary confinement only, or to such long periods in proportion to their confinement to hard labor as to render the labor wholly unproductive." 16

15 Wiscasset in Pownalborough, Wiscasset, 1941, p. 608.

16 Second annual report, p. 84. 
Here we see the economic motive of imprisonment mentioned for the first time in relation to this institution.

The first record of income from the labor in the prison is dated January 3, 1825 and shows: "at quarrying Lime Rocksales \$1431.45; profits, same; at hammering stone, sales, $\$ 113.55$; profits, same; shoe-making (raw material) $\$ 20.34$; sales, $\$ 202.29$; profits, $\$ 181.95$; all other employments, $\$ 28.88$; total profits $\$ 1755.83$." In 1826 the manufacture of oakum and lime casks was added.

The warden's salary for the first year was $\$ 400$ and that of the chaplain, $\$ 50$; the next year and for several thereafter the salaries were $\$ 800$ and $\$ 100$ respectively. These salaries were about the same as those paid in most other New Fngland penitentiaries at that time but it is interesting to notice that Captain Flam Lynds, warden of Auburn and later of Sing Sing, received $\$ 2,000$ annually.

The Thomaston site, like so many selected for penitentiaries, proved somewhat unsatisfactory, since at the outset it was found that the base upon which the cells were built was not granite as was originally thought. Hence, a granite groundwork had to be laid before the cells or pits were constructed. This naturally increased the expense. Each cell had stone sides so it was with great difficulty that a prisoner could climb them in order to reach the opening in a chance to escape. Yet, no sooner was the prison opened than one Ellers, a convict, broke out and Dr. Rose "who had prided himself on having a prison from which escape was impossible, felt mighty chagrined at this contretemps." Two searching parties were dispatched from the prison, one bound for Canada, the other for Augusta. One of the parties captured a man who didn't deny he was Fllers nor, naturally, did he admit it and the posse, convinced that it had the man wanted, notified the other party to return. Later it was seen that the captured man was not the fugitive but merely a good friend of his who had decided not to admit voluntarily the case of mistaken identity. Thus, the first escapee from the Maine State Prison was never captured. ${ }^{17}$

The inspectors, in 1826, were disturbed about the housing of female prisoners. In their words, we find:

Another and important and embarrassing matter is the confinement of females in the prison where no arrangements have been exclusively made for their confinement, employment and government. It is a subject they approach with diffidence and touch with reluctance; they will venture, however, to declare their opinion not lightly or immaturely

17 From Rockland Courier-Gazette, loc. oit. 
formed that the females should be excluded not only from the observation of the male prisoners, but from personal intercourse and communication with male officers of the prison. This subject should not be permitted to escape the attentive consideration of the government.

And while a small building was erected to house the women in 1828, which cost the small sum of $\$ 172.17$, the inspectors reported in that same year that "a convenient local disposition and employment of female convicts remains a troublesome and perplexing affair." In fact, the inspectors of the prison in 1886 reported that "the lapse of sixty years has done but very little to remedy the difficulty and they cordially endorse the statements of the inspectors of 1826 (relative to the treatment of females.) ',

When the system of solitary confinement was abolished by act of February 1, 1827 the legislature, prompted by the experience of the prison for the preceding years, enacted the following three provisions:

(1) that when any person shall be sentenced to imprisonment for a term less than six months, such sentence shall be executed in county jail, and not in the State Prison, unless from the character and circumstances of the convict, imprisonment in the county jail shall to the court appear unsafe and improper;

(2) that when any female, or any person under the age of eighteen years shall be convicted, the sentence shall be executed in the jail of the county, unless from the circumstances of the case such imprisonment shall to the court appear unsuitable or inadequate; and (3) that all punishments by imprisonment in the State Prison shall be confinement to hard labor, and not by solitary confinement; providing that nothing herein contained shall preclude the use of solitary confinement as a prison discipline for the government and good order of the prisoners. ${ }^{18}$

The warden, during the year 1826, had experimented with drunkards, according to Rev. Louis Dwight of the Boston Prison Discipline Society. In fact, it seems that several prisons were the scene of the same-type of experimentation, especially in those of New England, Dwight records :

An important experiment has been made . . . of the effect on health, of cutting off habitual drunkards, at once, from the use of spirituous liquors, in every form, and confining them to cold water. It has been found invariably beneficial. They soon renew their youth; and a more hale, healthy, muscular body of men cannot be found in Prison, or out of Prison, than the cold water convicts, in the quarry of the Maine Prison. It is an experiment, also, to show that hard labor can be performed on good food and cold water. As evidence of this, it is only necessary to see these men handle rocks. ${ }^{19}$

But Dwight found many evils in the Maine prison. They were evil communication, particularly in the cells where two are confined

18 Boston Prison Discipline Society report (second), p. 86.

19 Tbid., p. 85. 
together; a disposition in old convicts to associate themselves with the youth, which has been carefully prevented as far as possible by the warden; procuring spirituous liquors and cards in a few instances from assistant keepers, who have been discharged; a want of vigilant inspection in the shops during the day, which arises from the great diversity of employments, and the number of small shops, and which it is contemplated to prevent by making the business more simple; the expense of the establishment (more than $\$ 1,000$ last year) which will be diminished by the new rules and regulations; [no more solitary confinement with idleness] and the want of instruction. The Prison has bcen furnished with only one short religious service on the Sabbath, and no instruction of any kind at any other time. ${ }^{20}$

In spite of the above bill of particulars showing deterioration in administration and lack of religious instruction, the Council Records show that on March 7, 1825 a small library was provided "consisting of moral and religious books for the use of the convicts."

The second warden of the Maine prison was, as mentioned earlier, Hon. Joel Miller. Miller was born in Lincolnville, Maine about 1784 and moved to St. George where he married Elizabeth Robinson. He became warden in 1828 and was also state senator in the same year. After he retired from his/prison post, in 1836, he was elected probate judge. He died September 10, $1849 .{ }^{21}$ The wardens of the Maine prison up to the time of the War Between the States, in chronological order, were:

Daniel Rose, Boothbay. . . . . . . . . . . . . . . 1824-1828

Joel Miller, St. George. . . . . . . . . . . . . . . 1828-1836

John O'Brien, Thomaston. . . . . . . . . . . 1836-1839

Benjamin Carr, Palermo.............. 1839-1850

Col. William Bennett, Ellsworth. . . . . . . . 1850-1855

Thomas W. Hix, Rockland. . . . . . . . . . . 1855-1856

William Bennett . . . . . . . . . . . . . . 1856-1857

Thomas W. Hix. . . . . . . . . . . . . . 1857-1861

Richard Tinker, Ellsworth ${ }^{22} \ldots \ldots \ldots \ldots \ldots \ldots$ 1861-1863

Warren Rice, Union................ 1863

Aside from the reports of the inspectors, wardens and chaplains throughout the years, we get some notions concerning the administration of the prison during the next dozen years from the reports of the Boston Prison Discipline Society, to one of which we have already alluded. It was stated in the 1830 (Fifth) report that a Sabbath School was established during the

20 Ibid., p. 85.

21 Eaton, op. cit., vol. II, p. 329.

22 Warden Tinker was murdered May 13, 1863 by a convict, one Francis Spencer Couillard. Tinker was the only official ever assaulted in this prison-at least up to 1915. Couillard was hanged in the prison yard. 
year and the warden wrote that the legislature had appropriated $\$ 75.00$ to purchase books for use of the prisoners. $\mathrm{He}$ added that he noted the convicts had "become more industrious and obedient" because of it! He further hoped that "by divine assistance-without which all our efforts will be ineffectual," added the Rev. Dwight_- "a different result than formerly will be produced in the morals and deportment of the convicts."

In the next report-1831-we find the following which is worthy of record:

The Prison contains about as many solitary cells as convicts. These cells are so constructed and arranged that evil communication is in a great measure, if not entirely, prevented, while the men are confined in them, which is about one half of the whole time. We believe that each cell is furnished with a Bible, and that the cells are so constructed as to admit light enough to read in the daytime. A large part of the time, therefore, is spent, by the convicts in this Prison, in silence and solitude, with the Word of God in their hands; so that those who can read, if they are disposed, have a favorable opportunity to read the Bible, without shame, and with none to take the good seed out of their hearts, at the moment it is planted; and those who cannot read; can think. In compassion to those who cannot read, a Sabbath School has been instituted, where they can learn. ${ }^{23}$

That the Maine State Prison failed to live up to the fond expectations of its founders and early friends may be gleaned from reports of inspectors as well as of the wardens. However, no prison yet devised lias ever been successful in reforming or disciplining prisoners judged by standards of penal treatment held by contemporary authorities. We see the following as examples of despair during those early years.

As early as 1825 the inspectors say that the results "from causes wholly out of their control do not fully accord with the pleasing anticipations entertained by them at the commencement of the year." In February 1830 Governor Hunton stated in his message :

I would particularly recommend the examination of the causes which have rendered our state prison so expensive as compared with other states. If the location is such that the prison cannot by the best management, be rendered other than a perpetual and heavy expense to the state, the sooner the legislature knows it, the better.

In 1835 , eleven year's after the prison was built, Governor Dunlap appointed a Commission with Hon. William D. Williamson at its head, to consider the prison and its interests. One year later they reported that a new prison should be erected in the vicinity of the State House at Hallowell. The same year the warden complained that the cells were so constructed that no warmth could by any means be communicated to the prisoners.

23 p. 434. 
In 1837, Governor Dunlap stated in his message: "The prison seems to have been constructed with a view to inflict the greatest punishment in the shortest time, and at least expense." In 1842 the inspectors say: "The cause of humanity calls aloud for reform and in vigorous and emphatic words asks for, or demands, a new prison.",24

In 1843 a new wing was finally erected costing $\$ 13,500.00$. This led the warden, Benjamin Carr, to remark: "We now have as good a prison as there is in the Union." In conducting visitors through the new wing, the inspectors proudly exclaimed:

It must be cheering to the Philanthropist to hear that Maine has now a prison that is not a disgrace to her; one that is second to none in the country for convenience, comfort, and security.

This new wing, the best description of which is found in the Rev. Dwight's twentieth report (1845) page 60, was nothing more than a conventional Auburn inside cellblock, two tiers of cells placed back to back. Here is the description:

The new prison consists of 108 cells of split granite. The building is three stories high, with 38 cells in each story, two abreast, with a longitudinal wall of bricks forming the backs of the cells. Each cell has a ventilator, carried up separately through the wall, which empties itself into a granite trough, which passes the whole length of the building. On this trough are placed two chimneys which earry off all the bad air from the cells. The cells are 7 feet long, 7 feet high and 4 feet wide, in the clear. Fach cell contains an iron bedstead, the frame of which is made of one-inch round iron, and filled with narrow hoop iron. When the convict is not in bed, this is turned up and fastened.

The area between the outer prison and cells is 11 feet wide and 25 feet high, well lighted by large windows. The windows move on pulleys and weights, so that each morning the prison is aired by dropping the windows, which drives the bad air up the flues of the cells and leaves the prison pure and elear. The whole inside of the outer prison is plastered with three coats of lime mortar, and all the cells, inside and outside, are well whitewashed. The floor in the area is also made of split granite and whitewashed. The windows have green blinds on the inside, for the protection of the night watch. The doors, railings, etc., are painted black. The cells are warmed by four boxstoves placed in the area. ${ }^{25}$

The new wing cost $\$ 13,177.44$. While it was under construction the prisoners made considerable trouble for the warden. $\mathrm{He}$ stated in his report: "While taking away the western wing of the old prison, which constituted part of the prison wall, frequent plots were made hy them (the prisoners) to escape, and some of them were successful." The inspectors stated that much of the materials in the old cells was used for the new con-

24 The above quotations are taken from the minority report of the Commissioners on the Removal of the Maine State Prison, 1891-James Woodbury of Bangor minority member; E. H. Lawry and W. H. Jackson, majority.

25 Ibid. 
struction and while the work was going on some of the prisoners "had good opportunity to lay plans and conduct mischief." They advocated that six or eight of the old cells should be maintained for purposes of punishment; that since the completion of the new cells, the prisoners "dread solitary confinement, as it is inflicted by placing them in the old cells, which they soon find by contrast, to be a terror to evil-doers; that it requires but a very short confinement in those dark, damp dungeons, to bring even the most refractory to good behavior." "26

It is interesting to note that the Rev. Job Washburn, appointed chaplain in 1824 was still administering to the prisoners in 1845. $\mathrm{He}$ reported in that year regarding his work and the prisoners' reactions :

We have had two religious services on the Sabbath, one commencing at 80 'clock, A.M., the other at 3 o'clock, P.M. The Sabbath School is in connection with the afternoon service, and has consisted of four classes; two are Bible classes, the other two are instruction from the spelling-book. Of those who form the classes most of them appear much interested.

Although some of the convicts appear totally regardless of the claims of their Maker, and insensible to the worth of their souls, yet I am happy to say that such appearances are not general, for the largest part of them are attentive to the word preached, and not unfrequently give proof of deep inward emotions.

And he adds a few words regarding the new prison block:

I take great pleasure in being able to say that the new Prison cannot fail to meet the wishes and desires of a humane and feeling community. This spacious building reflects honor to our state, and much credit is due to those who have had the management of its construction. Those who have friends here confined ... may rest assured that it is every thing - for light, warmth, neatness, and comfort-that a Prison possibly could be.

With compassion for the unfortunates placed under me, as their spiritual guide, relying on the power of goodness of a merciful God to give success to my feeble efforts, and requesting an interest in the prayers of the godly, that I may so discharge my duties as to savingly benefit souls, and meet the approval of my God and judge.-Thomaston, January 1845.

This new cellblock did not last long. Most of the prison was destroyed by fire on December 22, 1850. A contemporary report on the fire states:

the roof fell in with a crash just as the last division (of prisoners) was removed from the dormitory building. They labored faithfully to extinguish the flames without any attempt to escape; and afterwards behaved so well although crowded together in narrow quarters, till they could be restored to the dormitory building. During a period of two weeks of this confused and crowded state, the prisoners did not require to be reproved; so orderly and good was their behavior, which

26 Boston Prison Discipline Society report (Twentieth), p. 59. 
the warden attributes to their good habits, established by systematic and thorough discipline. ${ }^{27}$

Construction following the fire was: a main building of stone erected in 1851; the completion of the stone wall around the entire yard, in process for many years, completed in 1854; a guard house built in 1855 . Thus the prison management attempted to carry on with a patched up plant until the famous Blaine report of 1858 which excoriated legislatures, wardens, boards of inspectors for the many preceding years. Still, however, little constructive planning resulted. In 1858 it was noted that the number of prisoners had so increased-128 in that year which, for Maine, was considered large-that an appropriation of $\$ 13,000.00$ was made for remodeling and expansion. But again nothing was accomplished. The architect, Gridley J. F. Bryant, felt that this sum was totally inadequate for the scope of the work. He felt that a totally new institution was necessary. He stated that the old Auburn cellblock erected only fifteen years earlier-in 1843-was "extremely faulty by its cramped and badly ventilated cells, its narrow galleries, stairs and areas and its lack of light in the exterior walls.",28 Yet, it must be remembered that those enthusiasts who had negotiated the erection of this inside block considered it modern and in every respect "second to none in the Union."

It is not the purpose to carry the history of the Maine prison beyond its early years. A great deal has happened to it since 1858. Perhaps the most thorough study made of its long administration was that submitted to the legislature by Hon. James G. Blaine in 1858. ${ }^{29}$ It might be suggested that this report divides the old from the new although a real modern plant did not materialize until a devastating fire swept through the institution in 1923 making it imperative that a complete renovation be made.

A few items of interest regarding the prison since the turn of the century are: in 1907 it was reported that the prisoners were making carriages, sleighs, harnesses and brooms; also during this year congregate eating replaced the serving of meals in the individual cells. In that year mentally diseased prisoners were removed to the institution at Augusta where cases of this type are housed. Farlier, in 1901, the old lime pits, or quarry, which had been an eyesore for so many years, were filled in. This open excavation was filled with near-stagnant water and

27 Boston Prison Discipline Society report (Twenty-seventh), 1852, p. 683.

28 Report on the Disbursement, Labor and Discipline in the Maine State Prison, report of a Commission appointed March 27, 1858 and published in 1859.

29 Ibid. 
[Vol. 38

called for serious indictment throughout the years on the part of wardens, inspectors and casual visitors. Often referred to as a cesspool it was some 400 feet long, 145 wide and 70 deep and much of the prison sewage seeped into it. It was a happy day for the prison when this yawning hole was finally filled in.

The old Maine prison was finally and completely destroyed by fire on September 15, 1923. As one writer described the event:

Fire swept every vestige of the antiquated and dilapidated buildings - and crumpled to the ground, as if built of cardboard, the centuryold Bastille, the old west wing, built to withstand the ravages of time or elements and saturated with unsavory reminders of the past, whether an honest or dishonest fire, was a fortunate happening.

These words were spoken at the dedicatory services of the new prison which was erected on the same site, on the ruins of the older structure on September 11, 1924.

This account is not intended to be an exhaustive history of the Maine State Prison, and certainly it does not envisage anything of the modern contemporary plant or administrative setup. Rather, the attempt has been made merely to collect fragmentary . items of interest concerning the institution and weave them into a story with some degree of continuity. Some of the material is definitely unique but much of it is simliar to that dealing with many other prisons of early United States.

\section{$365^{-}$




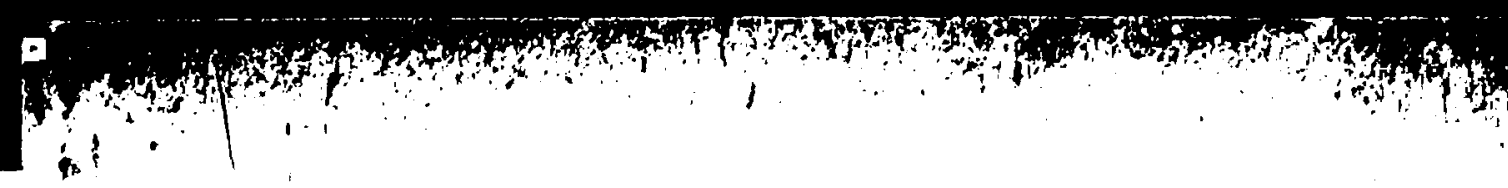


